DOI: $\underline{\text { https://doi.org/10.15407/techned2020.03.083 }}$

\title{
PHASE LIGHT RANGERFINDER WITH ADAPTIVE OPTICAL CALIBRATION SYSTEM
}

$\quad$ Journal
Publisher
ISSN
Issue
Pages

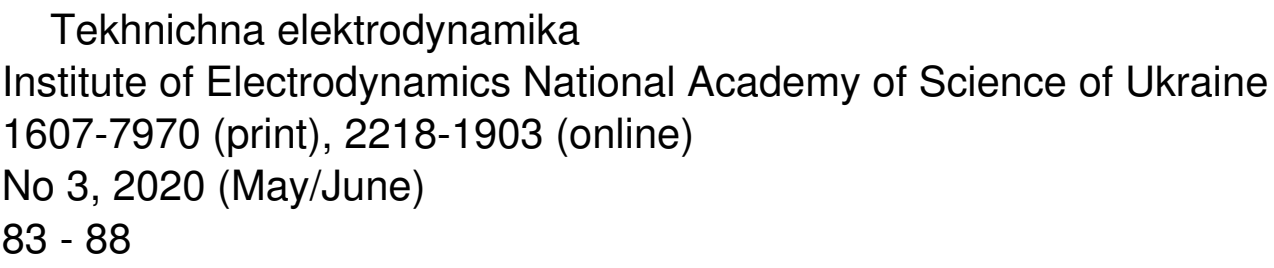

\section{Authors}

\section{I.O. Bragynets*, Yu.O. Masjurenko**}

Institute of Electrodynamics National Academy of Sciences of Ukraine, pr. Peremohy, 56, Kyiv, 03057, Ukraine, e-mail: masjuriy@ied.org.ua

* ORCID ID : https://orcid.org/0000-0002-9528-5808

** ORCID ID : https://orcid.org/0000-0003-4209-1126

\begin{abstract}
The error of phase laser range finders, which is due to the difference in the initial phases of the signals in the modes of distance measurement and optical calibration, is determined. An algorithm for measuring the phase shift of the signal reflected from the object, which ensures the equality of the initial phases in both operation modes of the device, is described. This allows to significantly improving the speed of the rangefinder while maintaining the specified measurement accuracy. The structural diagram of the phase light range finder, which implements the proposed distance measurement algorithm, is considered. References 5, figures 2 .
\end{abstract}

Key words: laser, phase shift, optical calibration, initial phase, adaptation. 
Published: 05.05.2020

\section{References}

1. Bolshakov V.D., Deimlikh F., Golubev A.N., Vasilev V.P. Radio geodesic and electro-optical measurements. Moskva: Nedra, 1985. 303p. (Rus)

2. Stierle J., Wolf P., Renz K. Device and method for optical distance measurement. Patent US. No 7221435 B2. 2007.

3. Venediktov A.Z. Laser ranger finder. Patent Rossii. No RU2339909C1. 2007. (Rus)

4. Skripnik Yu.O. Improving the accuracy of measuring devices. Kiev: Tekhnika, 1976. 264 p. (Rus)

5. Bragynets I.O., Kononenko O.G., Masjurenko Yu.O. Lazernyi dalekomir. Patent Ukrainy. No 134816. 2018. (Ukr) DOI: https://doi.org/10.15407/publishing2018.49.103

$\underline{\text { PDF }}$

This work is licensed under a Creative Commons Attribution-NonCommercial-NoDerivatives $\underline{4.0 \text { International License }}$ 